\title{
PENERAPAN DALUWARSA PENETAPAN DALAM PENERBITAN SURAT TAGIHAN PAJAK BUNGA PENAGIHAN
}

\author{
Suparna Wijaya \\ Politeknik Keuangan Negara STAN \\ sprnwijaya@pknstan.ac.id \\ Ulrich Zwingly Putra Pardede \\ Direktorat JenderalPajak \\ ulrichzwinglyputrapardede@gmail.com
}

\begin{abstract}
ABSTRAK
Daluwarsa penerbitan STP Bunga Penagihan tidak diatur secara jelas dalam UU Ketentuan Umum dan Tata Cara Perpajakan (UU KUP). Kemudian diterbitkan Peraturan Pemerintah 74 tahun 2011 yang seharusnya menjelaskan lebih lanjut, tetapi belum juga memberikan kepastian hukum. Dalam PP 74 tahun 2011 menyatakan jangka waktu penerbitan STP dan SKPKB itu sama, yaitu 5 tahun sejak berakhirnya tahun pajak masa pajak atau bagian masa pajak, kemudian tidak ada penjelasan mengenai STP jenis apa yang dimaksud, sehingga sangat banyak interprestasi dari berbagai pihak sehingga menimbulkan bias hukum. Penelitian ini bertujuan untuk mengetahui dasar hukum penerbitan STP Bunga Penagihan, pelaksanaan penerbitan STP Bunga Penagihan di kantor pajak serta berbagai interpretasi narasumber yang berhubungan dengan penelitian ini. Penelitian ini merupakan penelitian kualitatif dengan metode literasi dan penelitian lapangan dalam bentuk wawancara. Penelitian ini memberikan hasil dimana banyaknya dasar hukum yang mengatur tentang penerbitan STP Bunga Penagihan tetapi tidak menyatakan jangka waktu penerbitan dengan jelas. Ketidakjelasan tersebut pun dapat diatasi dengan pandangan pegawai Direktorat Jenderal Pajak Republik Indonesia dan narasumber-narasumber lain yang cenderung serupa mengenai jangka waktu penerbitan STP Bunga Penagihan. Studi kasus terhadap putusan pengadilan yang relevan juga dijelaskan dalam jurnal ini.
\end{abstract}

\section{Kata Kunci: Bunga Penagihan; Daluwarsa; Undang-Undang}

\section{ABSTRACT}

The expiration of the issuance of STP Bunga Penagihan is not clearly regulated in the Law on General Provisions and Tax Procedures (UU KUP). Then the Peraturan Pemerintah 74 of 2011 was issued which should explain further, but has not yet provided legal certainty. PP 74 of 2011 states that the period of issuance of STP and SKPKB is the same, namely 5 years from the end of the tax year or part of the tax period, then there is no explanation of what type of STP is meant, so there are so many interpretations from various parties that cause bias law. This study aims to determine the legal basis for the issuance of STP Bunga Penagihan, the implementation of the STP Bunga Penagihan at the Tax Office and the various interpretations of the resource persons related to this research. This research is a qualitative research using literacy methods and field research in the form of interviews. This research gives results where there are many legal bases governing the issuance of STP Bunga Penagihan but do not clearly state the period of issue. This ambiguity can also be resolved with the views of the staff of the Directorate 
General of Taxes of the Republic of Indonesia and other informants who tend to be similar regarding the period of issuance of STP Bunga Penagihan. Case studies of relevant court decisions are also described in this journal.

Keyword: Billing Interest, Expired, Constitution

\section{PENDAHULUAN}

Salah satu upaya untuk mewujudkan kemandirian suatu negara dalam keuangan pembangunan adalah dengan menggali sumber dana yang berasal dari dalam negeri dalam bentuk pajak (Ivon Trisnayanti \& Jati, 2015). Pajak merupakan salah satu sumber penerimaan negara yang memiliki kontribusi paling besar dalam membiayai proses pembangunan (Indriyati, 2019). Data Postur Anggaran 2019 menunjukkan bahwa kontribusi dari sektor pajak menjadi bagian terbesar bagi Pendapatan Negara. Berdasarkan data tersebut pajak memberikan kontribusi sebesar Rp1.786,4 T dari Total Rancangan Pendapatan Negara 2019 Rp2.165,1 T (kemenkeu.go.id). Berarti pendapatan pajak memberikan fungsi sangat besar sekitar $82,5 \%$ dari total seluruh penerimaan Negara.

Pasal 1 ayat 1 Undang-Undang Nomor 6 tahun 1983 tentang Ketentuan Umum dan Tata Cara Perpajakan sebagaimana telah diubah terakhir dengan Undang-Undang Nomor 16 tahun $2009 \quad$ (Undang-undang KetentuanUmum Perpajakan/UU KUP) juga

menyatakanbahwaPajakadalahkontribus iwajibkepada negara yang terutang oleh orang pribadiatau badan yang bersifat memaksa berdasarkan Undang-Undang, dengan tidak mendapatkan imbalan secara langsung dan digunakan untuk keperluan negara bagi sebesar-besarnya kemakmuran rakyat.

Sebelum ditetapkan sebagai Wajib Pajak, setiap orang harus sudah memenuhi syarat sebagai Wajib Pajak yaitu syarat objektif dan subjektif. Di Indonesia, wajib pajak dapat melakukan kewajiban perpajakan dengan 2 (dua) sistem yaitu self assessment dan official assessment. Official Assessment yaitu petugas pajak berwenang dalam menentukan jumlah pajak yang terutang sedangkan Self Assessment yaitu member kepercayan dan kebebasan kepada Wajib Pajak untuk menghitung, melaporkan, memperhitungkan dan membayar sendiri besarnya pajak yang harus dibayar (Yusuf, 2011).

Direktorat Jenderal Pajak memberikan ketentuan Wajib Pajak harus melakukan kewajiban perpajakan menggunakan sistem self assessment. Hal ini dikarenakan Wajib Pajak lebih bebas dalam menentukan jumlah pajak terutangnya. Salah satu hal yang diharapkan sistem self assessment ini adalah peran aktif serta kejujuran dari masyarakat dalam melakukan kewajiban perpajakannya. Sehubungan dengan hal itu, pemahaman dan kepatuhan yang tinggi dari para Wajib Pajak adalah aspek yang paling penting 
dalam pengenalan self assessment system, karena dengan metode ini ada kemungkinan bahwa para wajib pajak tidak akan memenuhi kewajiban pajak mereka, mungkin karena ketidakmampuan, kesengajaan atau ketidakpedulian para wajib pajak sehubungan dengan kewajiban mereka (Ivon Trisnayanti \& Jati, 2015). Ketidakpedulian atas kewajiban pajak ini yang akan berdampak pada penerimaan pajak.

Wajib Pajak harus tetap jujur dalam menghitung pajak terutangnya. Apabila tidak menghitung pajak atau tidak memenuhi kewajiban perpajakan dengan benar maka petugas pajak dapat melanjutkan tindakan ketetapan. Ketetapan adalah suatu tanggung jawab Direktorat Jenderal Pajak untuk menghitung ulang pajak terutang yang sudah dibayar oleh wajib pajak jika ada bukti baru, yang akhirnya dapat menjadi kurang bayar, nihil bahkan lebih bayar. Cara pengujian yang dilakukan berupa pemeriksaan Surat Pemberitahuan (SPT) dan/atau ada keterangan lain yang membuat jumlah pajak terutang menjadi tidak benar.

Namun seiring berjalannya waktu, banyak Wajib Pajak yang melakukan pembayaran pajak dengan benar setelah terbit surat ketetapan pajak berdasarkan hasil pemeriksaan. Namun, Pasal 12 ayat (1) Undang-Undang KUP menyatakan: "Setiap Wajib Pajak wajib membayar pajak yang terutang sesuai dengan ketentuan peraturan perundang- undangan perpajakan, dengan tidak menggantungkan pada adanya surat ketetapan pajak". Maka itu sangat berlawanan dengan ketentuan peraturan perundang-udangan yang berlaku.

Apabila seseorang atau badan telah memenuhi syarat subjektif dan syarat objektif, maka memiliki kewajiban membayar pajak. Dalam UU KUP Pasal 38, 39 dan 39A menyatakan, apabila seseorang secara sengaja atau karena kealpaan tidak membayar pajak yang seharusnya dibayarkan, maka dapat dikenakan sanksi administratif maupun hukuman secara pidana. Sanksi administratif terbagi 3 (tiga) jenis yaitu sanksi bunga, denda dan kenaikan. Dalam Pasal 14 ayat 1c, menyatakan "Wajib Pajak dikenai sanksi administrasi berupa denda dan/atau bunga."

Sanksi bunga selanjutnya disebut sanksi bunga penagihan dikenakan kepada Wajib Pajak yang tidak atau kurang membayar utang pajak setelah tanggal jatuh tempo berakhir dan diikuti dengan tindakan penagihan aktif. Sanksibungapenagihan dan upaya penagihan aktif memiliki pengaruh sebesar $48,5 \%$ terhadap pembayaran tunggakan pajak, sisanya dipengaruhi oleh faktor lain (Indriyati, 2019).

Selain melakukan penagihan utang pajak yang belum dilunasi, petugas pajak juga perlu memperhatikan tindakan awal sebelum menerbitkan produk hukum yang digunakan sebagai dasar penagihan Pajak. Produk hukum 
tersebut terdiri dari surat ketetapan pajak, keputusan dan putusan. Surat ketetapan pajak dapat diterbitkan atas beberapa kondisi, salah satunya adalah setelah pemeriksaan. Pemeriksaan terjadi karena adanya ketidaksesuaian pajak terutang yang dihitung oleh wajib pajak dengan ketentuan yang diatur dalam peraturan perpajakan.

Sedangkan Surat TagihanPajak (STP) merupakan surat untuk melakukan tagihan pajak atau sanksi administrasi berupabunga atau denda (Pasal 1 ayat 20 UU KUP). Hal ini berarti STP berfungsi sebagai sarana untuk mengoreksi pajak terutang, memberikan sanksi kepada Wajib Pajak, dan menagih pajak. Permasalahannya adalah tidak seluruh surat ketetapan pajak dan Surat Tagihan Pajak dapat diterbitkan dengan tepat waktu oleh Direktorat Jenderal Pajak. Terkadang ada Surat Ketetapan Pajak (SKP) dan Surat Tagihan Pajak yang diterbitkan telah melewati jangka waktu penetapan atau sering disebut sudah daluwarsa.

Dalam Pasal 41 ayat (1) UndangUndang Nomor 19 Tahun 2000 tentang Perubahan atas Undang-Undang Nomor 19 tahun 1997 tentang Penagihan Pajak dengan Surat Paksa (UU PPSP) disebutkan, "Penagihan pajak tidak dilaksanakan apabila telah daluwarsa sebagaimana diatur dalam Undangundang dan peraturan daerah". UU PPSP tidak merinci seperti apa "telah daluwarsa" itu, dan pengertian "daluwarsa" sesuai dengan Undangundang atau Peraturan Daerah. Akan tetapi ditegaskan penagihan pajak tidak dilaksanakan, artinya tindakan penagihan pajak tidak boleh dilakukan oleh Jurusita Pajak apabila telah daluwarsa. Undang-Undang KUP juga sebenarnya tidak mengatur adanya daluwarsa penertiban STP dengan jelas. Oleh karena itu, ada yang menganggap penerbitan STP Bunga Penagihan tidak memiliki batas waktu sehingga menerbitkan STP melewati jangka waktu yang seharusnya. Maka, STP tersebut menjadi sia-sia dan tidak mempunyai kekuatan hukum lagi. Kepastian hukum diperlukan supaya wajib pajak lebih patuh terhadap pembayaran utang pajaknya. Penelitian ini akan diarahkan untuk menjawab berbagai masalah di atas terkait kepastian hukum atas daluwarsa suatu proses penagihan dan penerbitan Surat Tagihan Pajak atas bunga penagihan.

Penelitian terkait daluwarsa penetapan dalam STP Bunga Penagihan di Indonesia masih sedikit dilakukan. Berdasarkan penelusuran diketahui sudah ada beberapa penelitian. Adapun penelitian ini berbeda dengan (Samosir, 2018) yang meneliti utang pajak yang sudah daluwarsa. Sedangkan (Arifka, 2018) juga hanya meneliti sanksi administrasi bagi wajib pajak orang pribadi. Pun berbeda dengan (Ivon Trisnayanti \& Jati, 2015) yang menggunakan analisis regresi untuk membuktikan pengaruh penagihan 
pajak terhadap penerimaan PPN. Penelitian ini menunjukkan beberapa ketentuan penerbitan STP Bunga Penagihan yang tidak menyatakan jangka waktu penerbitan dengan jelas. Ketidakjelasan tersebut pun dapat diatasi dengan pandangan dari akademisi dan praktisi perpajakan di Indonesia. Studi kasus terhadap putusan pengadilan juga digunakan untuk lebih memberikan gambaran terkait STP Bunga Penagihan ini.

\section{KAJIAN LITERATUR}

\section{Pengertian Daluwarsa}

Menurut pasal 1946 KUHPerdata, daluarsa atau verjaring mempunyai arti alat untuk mendapatkan atau melepaskan sesuatu dari dalam suatu perjanjian karena berlalunya jangka waktu tertentu dan pada kondisi yang ditetapkan oleh hukum. Dalam pemberian hukuman, daluwarsa merupakan berakhirnya jangka waktu yang telah ditentukan dan berakibat hilang atau gugurnya hak untuk menuntut dan memberikan hukuman kepada orang yang melakukan tindak pidana (Helmi, 2016). Dalam prosedur pidana, dari semua tahapan peradilan, mulai tahap penyelidikan, kemudian penyidikan, penuntutan, persidangan, putusan hingga pelaksanaan putusan, daluwarsa diberlakukan pada tahap penuntutan dan pelaksanaan hukuman. Hal ini sesuai dengan pasal 78 hingga 85 KUHP (Azhar, 2018).

\section{Kepastian Hukum}

Kepastian hukum sangat membantu masyarakat dalam bertindak. Hal ini dikarenakan dalam asas hukum harus terdapat tuntutan etis. Maka asas hukum dapat dikatakan sebagai jembatan antara aturan hukum dan nilainilai sosial masyarakat dan pandangan etika publik. Di samping itu, untuk menciptakan ketentuan hukum, harus ada terciptanya asas utama yang membentuk kejelasan terhadap peraturan hukum, asas tersebut ialah kepastian hukum (Julyano \& Sulistyawan, 2019).

Dalam hukum terdapat 3 dasar yang saling bertemu. Apabila bersatu, maka akan membentuk suatu kesahan yang berlaku, yaitu Filsafati, Sosiologis dan Yuridis (Rahardjo, 2012). Keberadaan asas kepastian hukum merupakan sebuah bentuk perlindungan bagi yustisiabel (pencari keadilan) terhadap tindakan sewenang-wenang, yang berarti bahwa seseorang akan dan dapat memperoleh sesuatu yang diharapkan dalam keadaan tertentu (Julyano \& Sulistyawan, 2019).

\section{Teori Kepatuhan (Complience Theory)}

Faktor-faktor yang dapat membuat wajib pajak tidak patuh terhadap kewajiban perpajakannya (Rustiyaningsih, 2013). Ketidakpatuhan wajib pajak dapat menyebabkan penerimaan pajak sekaligus evaluasi bagi instansi perpajakan. Faktor tersebut adalah pemahaman Wajib Pajak 
terhadap self-assessment system, tingkat pendidikan Wajib Pajak, tingkat pelayanan yang diberikan oleh otoritas perpajakan, penghasilan Wajib Pajak, serta ketidakpedulian WP pada sanksi perpajakan.

Dalam dunia perpajakan, setiap wajib pajak yang taat dan patuh, akan mempermudah penerimaan pajak, sehingga tidak perlu melakukan tindakan penagihan. Teori kepatuhan (compliance theory) adalah pendekatan untuk struktur organisasi yang menggabungkan ide-ide dari model klasik dan partisipasi dalam manajemen(Lunenburg, 2012). Sedangkan menurut H.C Kelman, compliance diartikan sebuah ketaatan yang didasarkan atas pengharapan akan imbalan dan tindakan yang menjauhkan diri dari hukuman yang mungkin diterima (Anggraeni \& Kiswara, 2011).

Dalam melaksanakan kewajiban perpajakan, banyak faktor yang memungkinkan Wajib Pajak tidak patuh. Menurut Paul Webley, faktor yang mempengaruhi ketidakpatuhan wajib pajak adalah Keadilan (Equity), Kesempatan untuk tidak patuh (Opportunityof non compliance), Perbedaan Individual (Individual Difference), Norma-norma social (Social norm), Ketidakpuasan terhadap instansi pemerintah (Dissatisfaction with revenue authorities) (Kristanto \& Hayat, 2018).

\section{Asas Lex Specialis Derogat Legi Generalis}

Pengecualian dalam hukum juga sering terjadi. Maka dengan terciptanya ketentuan pengecualian ini muncul asas hukum baru dengan istilah, "Lex Specialis Derogat Legi Generalis" artinya interpretasi atas hukum yang menafsirkan bahwa hukum yang bersifat khusus (lex specialis) mengesampingkan hukum yang bersifat umum (lex generalis)(Helmi, 2016).

\section{Penagihan Pajak}

Penagihan Pajak sangat berhubungan dengan tingkat kepatuhan wajib Pajak. Penagihan pajak adalah tindakan yang dilaksanakan Direktorat Jenderal Pajak yang disebabkan ketidakpatuhan Wajib Pajak dalam hal perpajakannya serta melakukan kewajiban perpajakan yang tidak sesuai dengan ketentuan peraturan perpajakan, terkhusus pembayaran pajak terutang (Soemitro, 1996). Penagihanpajak juga upaya dari otoritas perpajakan kepada Wajib Pajak untuk membayar utang pajaknya besera biaya lain yang mengikutinya sesuai ketentuan perpajakan (Rusdji, 2005). Upaya yang dapat dilakukan adalah memberi teguran, menyampaikan surat paksa apabila teguran tidak diperdulikan, melakukan penagihan seketika dan sekaligus, mengusulkan pencegahan, melaksanakan penyitaan, melaksanakan penyanderaan terhadap wajib pajak serta melakukan pelelangan barang sitaan. 


\section{Sanksi Administrasi}

Sanksi hukum administrasi menurut J.B.J.M ten Berge merupakan inti untuk menjamin penegakan hukum administrasi. P de Haan menambahkan bahwa penggunaan sanksi administrasi adalah wewenang pemerintahan. Dan J.J Oosternbrink menambahkan sanksi administrative muncul dari hubungan pemerintah dan warga negara yang pelaksanaannya tanpa perantara pihak ketiga (kekuasaan peradilan) (Raharja, 2014). Di samping itu terdapat faktor yang menyebabkan timbulnya sanksi administratif. Faktor-faktor yang menyebabkan wajib pajak dikenakan sanksi administrative adalah karena kebiasaan lupa sehingga terjadi keterlambatan, karena kegiatan seharihari wajib pajak dan karena sering menunda pembayaran, serta ada juga yang tidak tahu tentang pajak serta tanggal jatuh tempoh pembayaran pajak yang hanya diketahui oleh sebagian orang (Arifka, 2018).

\section{METODE PENELITIAN}

Metode Penelitian yang dilakukan dalam penelitian ini adalah kualitatif deskriptif dengan menggunakan dokumentasi dan wawancara. Dokumentasi digunakan untuk mengumpulkan literasi dari berbagai sumber seperti ketentuan perpajakan dan aturan pelaksanaannya, buku-buku perkuliahan, jurnal, artikel, dokumen, ensiklopedi, kamus, majalah, dan lain sebagainya yang memiliki keterkaitan dengan topik penulisan karya ilmiah ini. Dalam wawancara harus berdasarkan petunjuk umum dan pewawancara harus menyusun kerangka kerja dan menguraikan poin-poin inti tetapi tidak perlu ditanyakan secara berurutan (Prastowo, 2011). Wawancara menggunakan narasumber yang berasal dari pejabat Direktorat Jenderal Pajak, Widyaiswara Pusat Pendidikan dan Pelatihan Perpajakan, dan Dosen jurusan pajak dari Politeknik Keuangan Negara STAN. Pengolahan data menggunakan triangulasi yang dilakukan dengan membandingkan pendapat narasumber dengan teori dan ketentuan perpajakan yang berlaku.

\section{HASIL PENELITIAN DAN PEMBAHASAN}

\section{Dasar Hukum Yang Mengatur Penerbitan STP Bunga Penagihan}

Undang-Undang KUP tahun 2009 tidak memberikan secara jelas mengenai jangka waktu dalam penerbitan STP Bunga Penagihan. Namun secara material STP Bunga Penagihan telah disinggung dalam Pasal 19 (1) UU KUP, namun penggunaan kata "Bunga Penagihan" baru digunakan di Surat Direktur Jenderal Pajak. Oleh karena itu sangat sulit memberikan kepastian hukum bagi wajib pajak. Atas dasar itulah diterbitkan turunan dari UU KUP $\begin{array}{llll}\text { yaituPMK } & 183 \quad \text { PMK.03 } 2015\end{array}$ (perubahan atas PMK Nomor 145/PMK.03/2012), PP 74 tahun 2011 
sampai Surat Direktur Jenderal Pajak No S-411/PJ.02/2016 yang dimaksudkan memberi penjelasan mengenai jangka waktu penerbitan STP Bunga Penagihan. Mengenai jangka waktu penerbitan STP Bunga Penagihan yang dinyatakan dalam PMK 145/PMK.03/2012 dan PP74 tahun 2011 hampir sama yaitu: "Surat ketetapan pajak dan/atau Surat Tagihan Pajak sebagaimana dimaksud pada ayat (1) dan/atau ayat (2) diterbitkan dalam jangka waktu 5 (lima) tahun setelah saat terutangnya pajak, atau berakhirnya Masa Pajak, BagianTahunPajak, atau Tahun Pajak ...". Ayat (1) dan (2) yang dimaksud adalah tentang penerbitan Nomor Pokok Wajib Pajak (NPWP) dan/atau dikukuhkan sebagai Pengusaha Kena Pajak (PKP) ataupun penghapusan NPWP atau pencabutan Pengukuhan sebagai PKP. Dengan demikian, istilah mengenai STP Bunga Penagihan belum digunakan dalam UU KUP, PP bahkan PMK di atas.

Selanjutnya dalam S411/PJ.02/2016 mulai dijelaskan mengenai jangka waktu penerbitan STP Bunga Penagihan dibagi menjadi 2 bagian, yang pertama adalah STP Pasal 7,8 9 dan 14 dan yang kedua adalah STP Pasal 19 UU KUP. Perbedaan dari kedua jenis STP ini adalah batas waktu penerbitan STP. Untuk STP Pasal 7,8,9 dan 14 jangka waktu penerbitan adalah maksimal 5 (lima) tahun setelah saat terutangnya pajak, atau berakhirnya Masa Pajak, Bagian Tahun Pajak atau
Tahun Pajak, untuk tahun 2008 dan sesudahnya.

Sedangkan untuk STP Pasal 19 diterbitkan paling lama dalam jangka waktu 5 (lima) tahun sejak Surat Ketetapan Pajak Kurang Bayar, serta Surat Ketetapan Pajak Kurang Bayar Tambahan, dan Surat Keputusan Pembetulan, Surat Keputusan Keberatan, Putusan Banding, serta Putusan Peninjauan Kembali, kecuali ada kondisi yang menyebabkan tertangguh untuk tahun 2008 dan sesudahnya.

Berdasarkan kedua penjelasan dalam surat Direktur Jenderal Pajak tersebut, maka walaupun dalam STP Pasal 7,8,9 dan 14 terdapat sanksi bunga, tetapi sanksi bunga yang dimaksud berbeda dengan sanksi bunga di STP Pasal 19. Sehingga, berdasarkan Surat Direktur Jenderal Pajak No. S411/PJ.02/2016 ini, terdapat pembedaan jenis-jenis STP dan berdampak pada pembatasan jangka waktu penerbitan Surat Tagihan Pajak. yang sebelumnya tidak ada perbedaan mengenai daluwarsa penerbitan tetapi berdasarkan surat ini terdapat perbedaan jangka waktu penerbitan jenis-jenis STP. STP Pasal 7,8,9 dan 14 selanjutnya akan disebut STP umum sedangkan STP Pasal 19 selanjutnya disebut STP Bunga Penagihan.

Berbagai pendapat di atas diutarakan oleh Irawan Budiono (DJP), Irwan dan Sulfan (Dosen PKN STAN), dan Rinaningsih (PusdiklatPajak). Hal 
ini sesuai bahwa daluwarsa merupakan berakhirnya jangka waktu yang telah ditentukan dalam hal ini terkait dengan jangka waktu penerbitan STP Bunga Penagihan (Helmi, 2016). Dengan adanya penjelasan dari DJP dalam S411/PJ.02/2016 ini juga memberikan kepastian hukum, sehingga tercipta kejelasan terhadap peraturan hukum (Julyano \& Sulistyawan, 2019). Sehingga DJP hendaknya berhati-hati dalam menerbitkan STP Bunga Penagihan ini dan kepala seksi penagihan selaku partisipasi manajemen hendaknya melakukan pengawasan terhadap jurusitanya (Lunenburg, 2012). Wajib pajak hendaknya taat dalam membayarkan ketetapan pajak, sehingga tidak dapat diterbitkan STP Bunga Penagihan, hal ini sesuai konsep imbalan dan menjauhkan diri dari hukuman sebagaimana dikemukakan Kelman (Anggraeni \& Kiswara, 2011).

\section{Daluwarsa Penetapan Dalam}

\section{Penerbitan STP Bunga Penagihan}

Berdasarkan wawancara yang dilakukan dengan beberapa narasumber, penulis memperoleh informasi yang cenderungsama, baik itu Irawan Budiono (DJP), Irwan dan Sulfan (Dosen PKN STAN), dan Rinaningsih (Widyaiswara Pusdiklat Pajak). Dalam penerbitan STP Bunga Penagihan seharusnya memakai daluwarsa penagihan bukan daluwarsa penetapan. Hal ini dapat dipermudah jika langsung melihat seksi apa yang menerbitkan
STP Bunga Penagihan. Kalau misal dalam penerbitan SKPKB sebagai produk hukum adalah seksi pemeriksaan sedangkan STP Bunga penagihan adalah seksi penagihan.

Tindakan penagihan bisa dilakukan apabila sudah ada utang yang definitif dan inkrah. Dalam produk hukum terdapat 2 konsep yaitu inkrah dan definitif. Berarti STP Bunga dapat diterbitkan atas produk hukum yang sudah inkrah atau definitif. STP bunga penagihan diterbitkan berdasarkan produk hukum yang sudah definitif dan inkrah. Contoh definitif adalah apabila diterbitkan SKPKB tetapi tidak dilunasi dalam jangka waktu 1 bulan sejak terbit, kemudian dalam jangka waktu 3 bulan sejak SKPKB dikirim tidak mengajukan keberatan, maka dapat dikatakan SKPKB tersebut sudah definitif. Berdasarkan SKPKB tersebut baru dapat diterbitkan STP Bunga Penagihan.

Dapat disimpulkan dari Irawan Budiono (DJP), maka jangka waktu penerbitan STP Bunga Penagihan 5 tahun sejak SKPKB atau produk hukum lain yang sudah inkrah atau definitive diterbitkan. Produk hukum berdasarkan pasal 19 ayat 1 UU KUP adalah Surat Ketetapan Pajak Kurang Bayar, Surat Ketetapan Pajak Kurang Bayar Tambahan, serta Surat Keputusan Pembetulan, Surat Keputusan Keberatan, Putusan Banding atau Putusan Peninjauan Kembali. 
Untuk daluwarsa penagihan SKPKB adalah 5 tahun sejak diterbitkan SKPKB tersebut dan daluwarsa penagihan STP Bunga Penagihan adalah 5 tahun sejak diterbitkannya STP Bunga Penagihan. Sehingga daluwarsa penagihan SKPKB atau produk hukum yang sudah inkrah atau definitive sama dengan daluwarsa penerbitan STP Bunga Penagihan .

Dalam penerbitan STP Bunga Penagihan seharusnya harus berhatihati, karena semakin lama menerbitkan, semakin besar hitungan bunganya. Sehingga apabila produk hukum sudah inkrah atau definitive tetapi sampai batas waktu pembayaran belum dibayar, maka dapat segera diterbitkan STP Bunga penagihan. Menurut narasumber, apabila menerbitkan STP bunga penagihan setelah pokok pajak dilunasi secara keseluruhan seharusnya tidak bisa karena saat penagihan pokok dan bunga itu satu kesatuan sehingga dapat dikatakan STP Bunga penagihan adalah bunga yang berbunga. Dasar yang dipakai adalah UU KUP karena Peraturan Pemerintah dan Surat itu masih dibawah Undang-undang.

Dasar hukum yang dipakai adalah UU KUP tersebut adalah Pasal 22 dan Pasal 19 ayat 1. Berdasarkan hal itu maka daluwarsa penerbitan SKPKB dan daluwarsa penerbitan STP Bunga Penagihan adalah berbeda. Berarti secara tidak langsung maka daluwarsa penagihan SKPKB atau produk hukum yang inkrah atau definitive sama dengan daluwarsa penerbitan STP bunga Penagihan. Menurut narasumber STP yang dimaksud dalam PP 74 tahun 2011 pasal 24 ayat 1 dan 2 adalah STP selain bunga penagihan.

Narasumber Irwan (Dosen STAN) menambahkan bahwa penetapan adalah perhitungan sendiri oleh Wajib Pajak yang contohnya adalah pajak terutang dalam Surat Pemberitahuan sedangkan ketetapan adalah penentuan besarnya pajak terutang berdasarkan pemeriksaan. Sehingga jika membahas produk hukum seperti Surat Ketetapan Pajak menggunakan daluwarsa ketetapan. Contoh dari ketetapan pajak itu adalah Surat Ketetapan Pajak Kurang Bayar, Surat Ketetapan Pajak Kurang Bayar Tambahan, Surat ketetapan Pajak Lebih bayar dan Surat Ketetapan Pajak Nihil.

Jangka waktu penagihan sudah diatur dalam UU KUP. Untuk tahun 2007 dan sebelumnya adalah 10 tahun sedangkan kalau 2008 dan setelahnya 5 tahun sejak diterbitkan Surat Tagihan Pajak, Surat Ketetapan Pajak Kurang Bayar, serta Surat Ketetapan Pajak Kurang Bayar Tambahan, dan Surat Keputusan Pembetulan, Surat Keputusan Keberatan, Putusan Banding, serta Putusan Peninjauan Kembali.

Bunga penagihan yang timbul merupakan bagian dari Surat tagihan pajak. termasuk juga bunga yang dimaksud dalam pasal 19 UU KUP. Penerbitan SKPKB dan produk hukum lain sudah diatur dalam UU KUP 
sedangkan untuk STP tidak diatur jangka waktu penerbitannya. Namun sekarang sudah ditegaskan kembali berdasarkan Surat Direktur Jenderal Pajak No S-411/PJ.02/2016. Berdasarkan surat ini sudah diatur mengenai jangka waktu penerbitan STP Bunga Penagihan. Sehingga tidak bisa sembarangan, dan harus ada batas waktunya.

Berdasarkan hal di atas, jangka waktu menerbitkan STP Bunga Penagihan adalah 5 tahun sejak diterbitkan SKPKB. Berdasarkan penjelasan dalam S-411/PJ.02/2016, untuk Tahun Pajak 2008 dan sesudahnya, STP Pasal 19 UndangUndang KUP diterbitkan paling lama dalam jangka waktu 5 (lima) tahun sejak Surat Ketetapan Pajak Kurang Bayar, serta Surat Ketetapan Pajak Kurang Bayar Tambahan, dan Surat Keputusan Pembetulan, Surat Keputusan Keberatan, Putusan Banding, serta Putusan Peninjauan Kembali, kecuali ada kondisi yang menyebabkan tertangguh.

Sedangkan apa yang dinyatakan dalam PP 74 tahun 2011 pasal 24 ayat 3adalah STP khususmengenai masa pajak, tahun pajak bukan atas bunga penagihan. Kategori yang termasuk STP selain bunga penagihan adalah STP Pasal 7, 8 ayat 2 dan 2a, Pasal 9 ayat 2a dan 2b. SKP dan STP memiliki kekuatan hukum yang sama, maksudnya adalah apabila SKPKB atau produk hukum tersebut tidak dibayar, maka dapat dilakukan penagihan dengan Surat Paksa.

Daluwarsa penagihan produk hukum seperti yang dijelaskan di atas sama dengan daluwarsa penerbitan STP Bunga Penagihan. Sebelumnya dibahas kalau daluwarsa penagihan dapat tertangguh, secara otomatis daluwarsa penerbitan STP Bunga Penagihan juga tertangguh. Narasumber berpendapat di dalam S-411/PJ.02/2016 tidak ada mengatur mengenai tertangguh, sehingga apabila daluwarsa penagihan tertangguh, tidak membuat daluwarsa penetapan STP Bunga penagihan juga tertangguh. Karena tertangguh itu konteksnya untuk tindakan penagihan sedangkan STP Bunga Penagihan adalah mengenai penerbitan. Oleh karena itu penerbitan STP Bunga penagihan dapat diterbitkan dalam jangka waktu 5 tahun sejak produk hukum diterbitkan dan tidak dapat tertangguh.

Dalam pengalaman narasumber, pernah menjumpai ada STP Bunga Penagihan yang tidak diterbitkan karena menganggap pokok saja tidak dibayar, apalagi sanksi bunganya. Namun apabila sudah dibayar pokoknya baru diterbitkan tagihan bunganya. Namun setelah dikeluarkan Surat S411/PJ.02/2016 ini, maka semakin jelas dan memberikan kepastian hukum bagi wajib pajak.

\section{Rinaningsih (Widyaiswara}

Pusdiklat Pajak) menyatakan daluwarsa penetapan adalah jangka waktu 5 tahun 
setelah saat terutangnya pajak atau berakhirnya Masa Pajak, bagian Tahun Pajak, atau Tahun Pajak, sebagaimana dimaksud dalam Pasal 13 ayat (1) dan Pasal 15 ayat (1) UU KUP. Hal ini untuk memberikan kepastian hukum bagi WP yang berhubungan dengan tindakan pemungutan pajak menggunakan sistemself-assessment, apabila telah lewat 5 (lima) tahun sejak saat terutangnya pajak atau berakhirnya Masa Pajak, bagian Tahun Pajak, atau Tahun Pajak, Direktur Jenderal Pajak tidak menerbitkan surat ketetapan pajak, maka pembayaran pajak terutang yang sudah dihitung oleh Wajib Pajak dalam SPT Masa atau SPT Tahunan secara otomatis menjadi tetap dan sudah menjadi pasti menurut hukum peraturan perundang-undangan perpajakan.

Surat Tagihan Pajak merupakan surat untuk melakukan tagihan pajak serta sanksi yang berbentuk bunga dan/atau denda serta kenaikan. STP merupakan sarana untuk menagih sanksi bunga dan/atau denda karena keterlambatan penyampaian SPT, keterlambatan penyetoran pajak, dan/atau karena Wajib Pajak tidak mematuhi ketentuan perundangundangan perpajakan.

Mengenai daluwarsa penerbitan STP tidak diatur dalam UU KUP. Namundemikian, seyogyanyapenerbitan STP dilakukanlebihawalsaat diketahuinya Wajib Pajak tidak melaksanakan ketentuan peraturan perundang-undangan perpajakan (terlambat menyampaikan SPT, terlambat menyetor, atau ketidakpatuhan). Hal ini berdasarkan prinsip efisiensi di mana pajak yang dipungut pada saat Wajib Pajak mampu untuk membayarnya.

Frasa "Bunga Penagihan"tidak terdapat dalam UU KUP. Frasa tersebut timbul karena terbiasa menyebutnya seperti itu. Ambigu jika menyebut Pasal 19 ayat (1) UU KUP sebagai bunga penagihan karena hal ini dapat membingungkan dalam pelaksanaan penagihan pajak. Pengaturan Pasal 19 ayat (1) hanya dikenakan terhadap pajak yang masih harus dibayar yang asalnya tercantum dalam Surat Ketetapan Pajak (SKP). Dengan demikian atas STP yang sampai dengan jatuh tempo belum dibayar, tidak dapat dikenakan sanksi Pasal 19 ayat (1) UU KUP. STP sebagaimana diatur dalam Pasal 14 ayat (1) UU KUP digunakan untuk menagih sanksi berupa denda dan/atau bunga. Sehingga atas sanksi berupa bunga yang diatur dalam Pasal 19 ditagih dengan menerbitkan STP.

Dalam penerbitan STP Bunga Penagihan narasumber mengatakan tidak terdapat pengaturan mengenai daluwarsa penetapannya, melainkan hanya daluwarsa penagihannya saja. Sebaiknya penerbitan STP dilakukan pada awal waktu sehingga STP yang diterbitkan dapat segera tertagih dan dibayar oleh Wajib Pajak, walaupun secara ketentuan formal (UU KUP) tidak mengatur batas waktu 
daluwarsauntukpenerbitan

STP.

Pendapat ini diperoleh baik dari Irawan Budiono (DJP), Irwan dan Sulfan (Dosen PKN STAN), dan Rinaningsih (Widyaiswara Pusdiklat Pajak).

\section{Studi Kasus Terhadap Putusan \\ Pengadilan Pajak Nomor PUT- 001982.99/2018/PP/M.IB Tahun 2018}

Pokok sengketa dalam putusan Pengadilan Pajak ini membahas mengenai gugutan wajib pajak terhadap Surat Keputusan Keberatan yang dikeluarkan DJP dengan Nomor KEP00347/NKEB/WPJ.07/2018 tanggal 2 Februari 2018 tentang Pembatalan Ketetapan Pajakatas STP Berdasarkan Pasal 36 ayat 1 huruf $\mathrm{C}$ karenapermohonanWajibPajakberkenaa ndengan STP PPh Masa PajakJuni 2011 Nomor 01030/106/11/081/16 tanggal 6 Oktober 2016. Dalam putusan ini terdapat 2 pembahasan yaitu terkait Daluwarsa Penerbitan Surat Tagihan Pajak (STP) dan terkait Materi Sengketa Gugatan. Berdasarkan putusan ini, penulis akan berfokus hanya terhadap pembahasan pertama yaitu mengenai daluwarsa penerbitan Surat Tagihan Pajak.

Pembahasan daluwarsa penerbitan Surat Tagihan Pajak sebagaimana yang dinyatakan dalam putusan pengadilan ini mempunyai fokus pada Surat Tagihan Pajak atas $\mathrm{PPh}$ untuk masa Pajak Juni 2011. Sehinga apabila dihubungkan dengan Surat Dirjen Pajak Nomor S-411/PJ.02/2016, maka STP dalam putusan ini tidak dikategorikan dalam STP Bunga Penagihan melainkan STP Pasal 9 UU KUP.

Dalam Risalah Putusan, Tergugat yaitu Direktorat Jenderal Pajak menyatakan bahwa STP diterbitkan berdasarkan Pasal 14 U KUP dan Pasal 13 UU KUP tidak mengatur jangka waktu penerbitan Surat Tagihan Pajak. Hal ini berbeda dengan Pasal 13 ayat 1 UU KUP yang mengatur dengan jelas jangka waktu penerbitan Surat Ketetapan Pajak Kurang Bayar, yaitu "dalam jangka waktu 5 (lima) tahun setelah saat terutangnya pajak atau berakhirnya Masa Pajak, bagian Tahun Pajak, atau Tahun Pajak, Direktur Jenderal Pajak dapat menerbitkanSurat Ketetapan Pajak Kurang Bayar dalam hal-hal...". Kemudian dalam Penjelasan Pasal 8 ayat 1 dan 1a, Tergugat berpendapat bahwa tidak ada daluwarsa penerbitan Surat Tagihan Pajak.

Selanjutnya

Tergugat menggunakan dasar hukum Pasal 24 PP 74 tahun 2011, dimana STP dapat diterbitkan dengan kondisi/ peristiwa tertentu sebagaimana disebut dengan jelas pada setiap ayat dalam pasal ini. Pasal 24 ayat 1 khusus untuk kondisi/peristiwa yaitu sebelum Wajib Pajak diberikan atau diterbitkan Nomor Pokok Wajib Pajak dan/atau dikukuhkan sebagai Pengusaha Kena Pajak dan Pasal 24 ayat 2 khusus untuk kondisi/peristiwa sebelum dan/atau setelah penghapusan Nomor Pokok Wajib Pajak atau pencabutan 
Pengukuhan Pengusaha Kena Pajak. Namun menurut tergugat Pasal 14 ayat 1 tidak dalam kondisi khusus sebagaimana diatur dalam Pasal 24 PP 74 tahun 2011, sehingga sangat berbeda.

Tergugat juga menyatakan bahwa jenis SURAT $^{1}$ yang digunakan oleh Penggugat bersifat intern atau khusus (tidak berlaku umum), sehingga tidak dapat menjadi dasar hukum. Berdasarkan beberapa hal di atas, Tergugat menyatakan penerbitan STP $\mathrm{PPh}$ Masa Juni 2011 No. 01030/106/11/081/16 sudah sesuai dengan peraturan perundang-undangan.

Dari sisi sebaliknya, Penggugat yaitu Wajib Pajak (PT. CFI) menyatakan STP PPh Masa tersebut telah melebihi jangka waktu penetapan. Hal ini didasarkan pada Pasal 48 UU KUP termasuk penjelasannya yang menyatakan "Hal-hal yang belum cukup diatur dalam UU ini, diatur lebih lanjut dengan Peraturan Pemerintah", sehingga Penggugat menggunakan PP 74 tahun 2011 sebagai aturan lanjutan. Di dalam Pasal 24 ayat 1, 2 dan 3 PP 74 tahun 2011, Penggugat menganggap bahwa STP No. 01030/106/11/081/16 menjadi bagian dalam Pasal tersebut sehingga seharusnya tidak dapat diterbitkan karena telah daluwarsa atau melewati jangka waktu 5 tahun setelah saat terutangnya pajak, atau berakhirnya masa pajak dan ditambah lagi Pasal 24
PP 74 tahun 2011 tidakdiajukanhak uji materiil ke Mahkamah Agung (MA) sebagaimana terlampir Putusan MA No. 73P/HUM/2013.

Selanjutnya

Penggugat menggunakan S-411/PJ.02/2016 tentang Penegasan Penerbitan STP yang diterbitkan Direktorat Peraturan Perpajakan I yang memberikan penegasan atas interpretasi Pasal $24 \mathrm{PP}$ 74 Tahun 2011. Dalam surat ini berfokus pada Romawi I huruf A angka 5 dan huruf $B$ angka 1 dan 2 yang menyatakan hal yang sama dimana jangka waktu penerbitan STP adalah 5 tahun setelah saat terutangnya pajak, atauberakhirnya Masa Pajak, bagianTahunPajakatauTahun Pajak. Berdasarkan UU KUP, PP 74 tahun 2011 dan S-411/PJ.02/2016 yang dijelaskan di atas, Penggugat menyatakan bahwa seharunya STP 01030 tidak dapat diterbitkan karena telah daluwarsa atau melewati jangka waktu 5 tahun setelah saat terutangnya pajak atau berakhirnya Masa Pajak.

Dari sisi Majelis ternyata mempertimbangkan PMK 145/PMK.03/2012 sehingga hasil penelitian Majelis terhadap UU KUP dan PMK 145/PMK.03/2012, majelis berpendapat dalam UU KUP maupun PMK tersebut tidak diatur ketentuan tentang batas waktu penerbitan STP dan Kedaluwarsa penerbitan STP. Kemudian, ketentuan yang diatur dalam Pasal 24 PP 74 tahun 2011 tersebut juga tidak relevan dengan sengketa, karena 
Penggugat tidak dalam posisi sebagaimana yang dimaksud dalam Pasal 24 ayat 1 dan ayat 2 PP 74 tahun 2011. Kesimpulan akhir yang diberikan Majelis adalah STP Nomor 01030/106/11/081/16, tidak kedaluwarsa.

Berdasarkan analisa penulis, bagian dalam putusan pengadilan ini tidak membahas spesifik mengenai STP Bunga Penagihan tetapi hanya terbatas pada STP secara umum. Namun, pembahasan dalam putusan ini sangat berhubungan dengan jangka waktu penerbitan STP Bunga Pengihan karena STP Bunga Penagihan merupakan bagian dari STP. Ketentuan mengenai batas waktu penerbitan STP belum diatur secara jelas dalam UU KUP. Selanjutnya PP 74 tahun 2011 dan PMK 145/PMK.03/2012 mulai mengatur mengenai jangka waktu penerbitan STP. Akan tetapi, keadaan Wajib Pajak dalam kasus ini tidak sesuai dengan ketentuan yang diatur dalam PP 74 tahun 2011 dan PMK 145/PMK.03/2012. Sehingga, karena kurangnya dasar hukum yang menyebabkanpenerbitan STP 01030 dikategorikan daluwarsa, maka STP yang diterbitkan oleh DJP tidak melewati jangka waktu penerbitan (tidak kedaluwarsa).

Oleh karena itu,hubungan yang dapat diperoleh adalah ketentuan yang diatur dalam PP 74 tahun 2011 dan PMK 145/PMK.03/2012 belum mencakup mengenai jangka waktu penerbitan STP Bunga Penagihan. Kemudian S-411/PJ.02/2016 tidak dapat digunakan menjadi dasar hukum dalam penerbitan STP Bunga Penagihan di pengadilan, melainkan hanya terbatas pada petunjukteknis di internal DirektoratJenderalPajak.

\section{PENUTUP}

\section{SIMPULAN}

Berdasarkan permasalahan dan pembahasan yang sudah dijelaskan dalam bab-bab sebelumnya, penulis memberikan kesimpulan sebagai berikut:

1. Terdapat beberapa dasar hukum yang mengatur mengenai penerbitan STP Bunga Penagihan. Untuk memberikan kepastian hukum, dasar hukum yang dapat digunakan Wajib Pajak yang meliputi UU KUP tahun 2009, Peraturan Pemerintah Nomor 74 tahun 2011, Peraturan Menteri Keuangan

(PMK)

Nomor183/PMK.03/2015

(perubahan atas PMK Nomor 145/PMK.03/2011). Sedangkan dalam melakukan tindakan penagihan Pajak di lingkungan Direktorat Jenderal Pajak ada beberapa dasar hukum yang dipakai yaitu Undang-Undang KUP tahun 2009, PMK 183 PMK.03 2015 (perubahan atas PMK Nomor 145/PMK.03/2012), PP 74 tahun 2011. Kemudian Surat Direktur Jenderal Pajak No S-411/PJ.02/2016 diperjelas dengan Nota Dinas ND- 
653/PJ.02/2018

dan

ND.1041/PJ.02/2018 yang dapat digunakan oleh petugas pajak yang berhubungan langsung dengan pelaksanaan penerbitan STP Bunga Penagihan.

2. Jangka waktu penerbitan STP Bunga Penagihan tidak diatur dalam UU KUP. STP Bunga penagihan dapat diterbitkan apabila sudah ada produk hukum yang kohir, inkrah dan definitif. Produkproduk hukum tersebut adalah Surat Ketetapan Pajak Kurang Bayar, Surat Ketetapan Pajak Kurang Bayar Tambahan, serta Surat Keputusan Pembetulan, Surat Keputusan Keberatan, Putusan Banding atau Putusan Peninjauan Kembali. Daluwarsa penagihan SKPKB atau produk hukum yang sudah inkrah atau definitif dimaknai sama dengan daluwarsa penerbitan STP Bunga Penagihan. Sehingga daluwarsa penerbitan STP Bunga Penagihan yaitu 5 tahun sejak diterbitkan produk hukum yang sudah inkrah atau definitive tersebut.

3. Putusan Pengadilan No. PUT001982.99/2018/PP/M.IB Tahun 2018 membahas mengenai STP Pasal 9 bukan STP Bunga Penagihan. Dalam putusan ini juga menyatakan UU KUP tidak diatur mengenai batas waktu penerbitan STP dan daluwarsa penerbitannya. Kemudian PP 74 tahun 2011 dan

\section{PMK} 145/PMK.03/2012 menjelaskan mengenai jangka waktu penerbitan STP tetapi hanya terbatas atas kondisi tertentu dan ternyata kondisi wajib pajak dalam perkara ini tidak sesuai dengan PP 74 tahun 2011 dan PMK 145/PMK.03/2012. Oleh karena itu, STP 01030/106/11/081/16 masih sesuai dengan peraturan perundang-undangan dan tidak kedaluwarsa.

\section{SARAN}

Berdasarkan simpulan tersebut, disarankan bahwa setiap kebijakan yang diambil Direktorat Jenderal Pajak (Pemerintah) harus memberikan kepastian hukum bagi warga negara. Ketentuan-ketentuan yang diambil terutama UU KUP dan Peraturan Pemerintah 74 tahun 2011 harus dapat menjelaskan batas waktu penerbitan STP Bunga Penagihan. Apabila masih kurang jelas, seharusnya Direktorat Jenderal Pajak (DJP) dapat menerbitkan peraturan baru yang dapat menjelaskan batas waktu tersebut. Oleh karena itu, tidak hanya internal DJP yang mengetahui, Wajib Pajak juga mengetahui ketentuan mengenai batas waktu penerbitan STP Bunga Penagihan.

\section{DAFTAR PUSTAKA}

Anggraeni, M. D., \& Kiswara, E. (2011). PEMANFAATAN
PENGARUH FASILITAS 


\section{PERPAJAKAN SUNSET POLICY TERHADAP TINGKAT KEPATUHAN WAJIB PAJAK. Universitas Diponegoro.}

Arifka, A. (2018). Sanksi Administrasi Bagi Wajib Pajak Pajak Penghasilan Orang Pribadi Di Kota Padang. Soumatera Law Review, 1(2), 233-250.

Azhar, H. (2018). Daluwarsa dalam Kuhp dan Fiqh Jinayah. CENDEKIA: Jurnal Studi Keislaman, 4(2).

Helmi, M. (2016). Ketiadaan Daluwarsa Penuntutan dalam Hukum Pidana Islam dan Pembaruan Hukum Pidana di Indonesia. Mazahib, 15(2), 196-207.

Indriyati, E. (2019). Pengaruh Sanksi Bunga Penagihan dan Tindakan Penagihan Aktif terhadap Pembayaran Tunggakan Pajak di KPP Madya Malang (Periode Januari 2014-Desember 2017). Universitas Negeri Malang.

Ivon Trisnayanti, I., \& Jati, I. (2015). Pengaruh Self Assessment System, Pemeriksaan Pajak, Dan Penagihan Pajak Pada Penerimaan Pajak Pertambahan Nilai (Ppn). E-Jurnal Akuntansi, 13(1), 292-310.

Julyano, M., \& Sulistyawan, A. Y. (2019). Pemahaman Terhadap Asas Kepastian Hukum Melalui Konstruksi Penalaran Positivisme Hukum. Jurnal Crepido, O1(01), 13-22.

https://ejournal2.undip.ac.id/index. php/crepido/article/download/6325
/3197

Kristanto, R., \& Hayat, M. A. N. (2018). Pengaruh Pengampunan Pajak dan Kemudahan Administrasi Pajak Terhadap Kepatuhan Wajib Pajak Orang Pribadi pada KPP Pratama Jakarta Penjaringan. Transparansi: Jurnal Ilmiah Ilmu Administrasi, 1(2), 218-234.

Lunenburg, F. C. (2012). Compliance Theory and Organizational Effectiveness. International Journal of Scholarly Academic Intellectual Diversity, 14(1), 1-4. http://nationalforum.com/Electroni c Journal Volumes/Lunenburg, Fred C Compliance Theory and Organizational Effectivenes IJSAID V14 N1 2012.pdf

Prastowo, A. (2011). Metode penelitian kualitatif dalam perspektif rancangan penelitian. Ar-Ruzz Media.

Rahardjo, S. (2012). Ilmu Hukum. Citra Aditya Bakti.

Raharja, I. F. (2014). Penegakan Hukum, Sanksi Administrasi Perizinan. Inovatif, 7(2), 117-138.

Rusdji, M. (2005). PPSP Penagihan Pajak dengan Surat Paksa. Indeks.

Rustiyaningsih, S. (2013). Widya Warta No. 02 Tahun XXXV / Juli 2011. Faktor-Faktor Yang Memengaruhi Kepatuhan Wajib Pajak, 01, 140151.

Samosir, H. H. (2018). DALUWARSA 


\section{SEHUBUNGAN DENGAN}

RESTITUSI PAJAK. 1, 520-537.

Soemitro, R. (1996). Pengantar Singkat

Hukum Pajak. PT. Eresco.

Yusuf, M. I. (2011). Analisis Determinan Pajak Pertambahan Nilai (PPN) Di Sumatera Utara.

Universitas Sumatera Utara. 